\title{
Psychological Capital Strengthens the Effect of Budget Participation on Budgetary Slack?
}

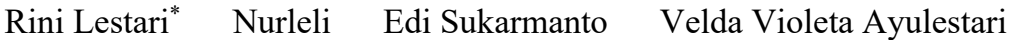 \\ Faculty of Economics and Business, Accounting Study Program,Universitas Islam Bandung
}

\begin{abstract}
This research is based on a phenomenon in the Bandung City Government, where there is still a reasonably significant difference between budget targets and budget realization. The existence of budgetary participation and psychological capital are essential factors that are expected to reduce budgetary slack. For this reason, this study aims to examine the effect of budgetary participation on budgetary slack and the effect of budgetary participation on budgetary slack moderated by psychological capital. This research was conducted in 22 Bandung City Regional Offices using verification research methods and quantitative approaches. This study uses primary data collected through the distribution of questionnaires and the determination of respondents is based on non-probability sampling and purposive sampling. By the established criteria, questionnaires were given to treasurers and parties who participated in budgeting at 22 Bandung City Regional Offices. The proposed hypothesis was tested using moderated regression analysis (MRA). The results showed that budget participation had a positive effect on budgetary slack, and psychological capital strengthened the influence of budgetary participation on budgetary slack. This research has implications especially for the Bandung City Government to pay more attention to setting more measurable budget targets, increase more significant influence, and increase confidence in individuals involved in budgeting.
\end{abstract}

Keywords: Psychological capital, budget participation, budgetary slack

DOI: $10.7176 / \mathrm{JESD} / 12-14-07$

Publication date:July $31^{\text {st }} 2021$

\section{INTRODUCTION}

Performance measures in general are the results that have been obtained by a person or group of people in a company by the authority and responsibility given. Although to achieve this performance, the planning function is indispensable for the company, one of the planning functions is a company budget. A budget is some targets set in the budget that can be achieved by implementing a series of activities that have been determined (Nafarin, 2015:11). Therefore, the budget can also be used to control and supervise the implementation in achieving the targets that have been set.

However, problems often arise in the budget preparation, which is too high, causing the budget too large. It can be shown from the low absorption of the budget itself. This condition of weak budget absorption also occurs in the Bandung City government. Of the budget realization report data budget year 2014 - 2017, from the target of budgets that have been realized over four years is always the differences between the budget that has been set with the realization that has been done, as presented in Table 1 below:

Table 1. Actual Budget 2014 to 2017 In Bandung City Government SKPD

\begin{tabular}{|c|c|r|r|l|}
\hline Year & $\begin{array}{c}\text { Budget } \\
\text { Expenditure }\end{array}$ & Actual Expenditure & Difference & $\%$ \\
\hline 2014 & 5.717 .545 .328 .505 & 4.435 .589 .826 .032 & 1.381 .955 .502 .473 & 77,58 \\
\hline 2015 & 6.553 .308 .797 .049 & 5.201 .938 .207 .165 & 1.351 .370 .589 .884 & 79,38 \\
\hline 2016 & 7.360 .848 .469 .022 & 5.830 .413 .791 .644 & 1.530 .434 .677 .378 & 79,21 \\
\hline 2017 & 6.752 .914 .685 .771 & 5.541 .718 .107 .062 & 1.211 .196 .578 .709 & 82,06 \\
\hline
\end{tabular}

Source: PPID Bandung

Table 1 shows that of all work achievements targeted in the budget, the average absorption capacity of budget realization is only $80 \%$. This means that there is always a difference in the Current Year's Budget Financing Remainder (SILPA). This condition is expected to occur again in the 2019 fiscal year. It was stated by Sumarna (2019) as the Regional Secretary of the City of Bandung) that the budget absorption of the Regional Apparatus Work Units (SKPD) in the City of Bandung until the end of October 2019 only reached 60 percent on average, and until the end of 2019, Sumarna estimates that the absorption capacity will only reach $80 \%$ (news.detik.com). This proves that the budget that has been set always occurs budgetary slack. The occurrence of budgetary slack can be caused by the high budget estimate. This condition can be seen from the comparison of the budget between 2016 and 2017. Although the 2017 budget is smaller (decreases) than the 2016 budget year, the absorption capacity of the budget still experiences a SILPA difference.

Budgetary slack that occurs, as stated by Anthony and Govindarajan (2005:86) can be caused by several factors, one of which is budgetary participation. Budget participation is a budget preparation process carried out 
by involving and cooperating between leaders and subordinates in making estimates and budget targets to be set (Mulyadi, 2001:513). However, in reality in preparing the budget, there is still a lack of participation given by superiors to subordinates. Based on the results of interviews as stated by Setiawan and Subagja (2016), the two members of the Bandung City DPRD said that this year they had a discrepancy in the achievements budgeted by the local government.

Likewise, Septiana \& Budiasih (2018) presented the results of interviews that budget gaps tend to be created by someone who has a suspicious character because the individual tends to experience doubts. Things are different when someone with an optimistic character because someone with a positive psychological character feels challenged against a high budget target. For this reason, the existence of individuals who have psychological capital is expected to suppress the negative impact that arises from budget participation on budgetary slack (Venkatesh, 2014).

Many studies related to the effect of budgetary participation on budgetary slack have been carried out. Research conducted by Young (1985), Dunk (2006), Jaya (2013), Tanaya \& Krisnadewi (2016), Rifqi \& Rahman (2017), Harryanto (2017), Pusporini, Haryadi \& Herwiyanti (2018), Basri, Rasuli \& Al-Azhar (2018), Pundarika\& Dwirandra (2019), Tahang, Usman \& Indrijawati (2018), Kepramareni, Pramesti \& Widiasih (2019), Mujiono, Chandrarin \& Assih (2019), Putra\& Astika (2019), Christina \& Akbar (2019), Apriwandi, Supriyono \& Arifa (2019), Oladele (2019), Wafiroh, Abdani \& Nurdin (2020), Carolina (2020), Ekayani, et.al (2021) showed the same results, namely budgetary participation has a positive influence on budgetary slack.

In addition to the two variables above, this study also uses psychological capital to moderate budget participation on budgetary slack. It has been stated previously that psychological capital is the capital of human attitudes and behavior that plays a significant role in determining success (Luthans et al., 2008) and the desire to create slack comes partly from individual-level characteristics with negative characters (Venkatesh, 2014). Other studies also show that when psychological capital is placed as a mediator of the effect of budget participation on budgetary slack, the results show that budgetary slack decreases (Nuryani et al., 2018) . Furthermore, from the previous description, the problems discussed in this study are 1) Does budget participation affect budgetary slack? 2) Is psychological capital able to moderate the influence of budgetary participation on budgetary slack?

\section{METHODS}

The research method used is a verification method with a quantitative approach (Sugiyono, 2017: 10), because this study will test the truth of the research hypothesis by using certain statistical techniques. Data collection techniques used in this study were questionnaires and documentation (Nazir, 2014:153). In this study, the independent variables are variables that affect other variables (Sekaran and Bougie, 2016: 118). In this study, the independent variable used is budgetary participation

1) Budgetary Participation

Budgetary participation is participation that involves the cooperation of managers and subordinates for budget decision making in determining budget targets (Anthony \& Govindarajan, 2004:408; Mulyadi , 2001:513). Budget participation is measured by the involvement of all levels of management in budgeting with the following indicators (Milani (Poerwanti, 2001:23)) :

1) Participation in budgeting

2) Reasons given by superiors when the budget is revised

3) Frequent initiatives to provide opinions at the time of budgeting

4) Influence on the final budget

5) Consideration of contributions to the budget

6) Frequency of superiors asking for opinions or suggestions when preparing the budget.

In addition, this study also uses the dependent variable, namely the variable that is influenced or is the result of an independent variable (Sekaran and Bougie (2016:116)). The dependent variable used in this study is budgetary slack.

2) Budgetary Slack

Budgetary Slack is a step make budgets to achieve targets that are more achievable, by budgeting lower revenues and higher costs than their best estimate of the amount (Suartana, 2016:137, Anthony \& Govindarajan, 2005:85), and Mardiasmo, 2007:36 ). According to Dunk (2006), the indicators used in this study are:

1) The ability of budget standards to encourage high productivity.

2) Ability to implement budget.

3) Ability in budget monitoring.

4) Whether or not there are special demands in the budget.

5) Ability to be responsible.

6) The general targets set in the budget are difficult to achieve.

In addition to independent variables and dependent variables, this study also uses moderating variables, namely variables whose position can influence (either strengthen or weaken) the relationship between 
independent variables and dependent variables (Sugiyono, 2014:43). In this study, the moderating variable used is psychological capital.

Psychological capital is the capital of positive human attitudes and behavior so that it plays a major role in determining increased performance (Luthans, et.al, 2008:220, and Venkatesh Blaskovic, 2012). According to Venkatesh Blaskovick (2012), in measuring psychological capital indicators used are:

1) Self-efficacy

2) optimism

3) hope

4) resiliency

Furthermore, this research is all treasurers in the Regional Apparatus Work Unit (SKPD) in the Bandung Municipality Area with the target population being all treasurers and parties involved in budgeting at the Regional Office in the Bandung Municipality area. While the sample used in this study were 74 treasurers and the parties involved in budgeting at the Regional Office in Bandung City with the sampling technique used was nonprobability sampling (purposive sampling) (Sekaran \& Bougie, 2016) with criteria (1) parties who play a role in preparing the budget, and (2) parties who serve as treasurers. The statistical technique used to test the hypothesis is simple linear regression analysis (to test the effect of the independent variable on the dependent variable without a moderating variable) and Moderated Regression Analysis (MRA) is a unique analytical tool from the regression analysis that contains elements of interaction variables or better known as moderating variable symbolized by the multiplication of two or more independent variables (Ghozali, 2013: 215). The purpose of using Moderated Regression Analysis (MRA) in this study is to determine whether the moderating variable can strengthen or weaken the influence of the independent variable on the dependent variable. In this study, the moderating variable used is psychological capital. Therefore, for usability testing of the second hypothesis, which is the capital of psychological strengthening the influence of budget participation on budgetary slack, the regression model used is:

$\mathrm{SA}=\alpha+\beta_{1} \mathrm{PA}+\beta_{2} \mathrm{PA} * \mathrm{MP}+\varepsilon$

Description: :

$\alpha \quad=$ Constant value

$\beta \quad=$ Regression coefficient

SA $\quad=$ Budgetary Slack

PA = Budget Participation

MP $\quad=$ Psychological Capital

$\varepsilon \quad=$ Error

After the correlation is calculated, it can be continued by calculating the coefficient of determination. The coefficient of determination measures how far the ability of capital to explain variations in independent variables (Ghozali, 2013). In its use, according to Sugiyono $(2017 ; 53)$, the coefficient of determination is expressed as a percentage which is formulated with the following formula :

$$
\mathrm{Kd}=\mathrm{R} 2 \times 100 \%
$$

Description:

$\mathrm{Kd} \quad=$ Coefficient of determination

$\mathrm{R} \quad=$ Correlation coefficient

\section{RESULT}

Based on the data obtained for the budget participation variable (PA) and the budgetary slack variable (SA), the results of the linear regression test are obtained as presented below.

Table 2. Linear Regression Results Without Moderating

\begin{tabular}{|c|c|c|c|c|c|c|}
\hline \multicolumn{6}{|c|}{ Coefficients $^{\mathbf{a}}$} \\
\hline \multirow{2}{*}{ Model } & \multicolumn{2}{|c|}{$\begin{array}{c}\text { Unstandardized } \\
\text { Coefficients }\end{array}$} & $\begin{array}{c}\text { Standardized } \\
\text { Coefficients }\end{array}$ & \multirow{2}{*}{ t } & \multirow{2}{*}{ Sig. } \\
\cline { 3 - 5 } & B & Std. Error & Beta & & \\
\hline \multirow{2}{*}{1} & (Constant) & 9.391 & 1.642 & & 5.719 & 0.000 \\
& PA & 0.215 & 0.085 & 0.726 & 8.448 & 0.000 \\
\hline
\end{tabular}

a. Dependent Variable: $S A$

Sumber : Data Processing Results, 2020

Based on the data obtained for the budget participation variable (PA), the budgetary slack variable (SA), and the MMP moderating variable (the result of multiplication between budget participation and psychological capital), the results of a linear regression test are obtained as presented below. 
Table 3. Results of Linear Regression with Moderating

\begin{tabular}{|c|l|c|c|c|c|c|}
\hline \multicolumn{2}{|c|}{ Model } & \multicolumn{2}{|c|}{$\begin{array}{c}\text { Unstandardized } \\
\text { Coefficients }\end{array}$} & $\begin{array}{c}\text { Standardized } \\
\text { Coefficients }\end{array}$ & \multirow{2}{*}{ t } & \multirow{2}{*}{ Sig. } \\
\cline { 3 - 8 } \multicolumn{2}{|c|}{} & B & Std. Error & Beta & & \\
\hline \multirow{2}{*}{1} & (Constant) & 12.504 & 2.543 & & 4.917 & 0.000 \\
& PA & -0.288 & 0.281 & 0.292 & 1.024 & 0.031 \\
& MMP & -0.008 & 0.005 & 0.454 & 1.590 & 0.012 \\
\hline
\end{tabular}

a. Dependent Variable: $S A$

Sumber : Data Processing Results, 2020

The results of the simultaneous significance test ( $\mathrm{F}$ test), both without moderating and with moderating are presented in Table 4.35 and Table 4.36 below:

Table 4. Results of F Test Without Moderating

\begin{tabular}{|l|l|r|r|r|r|r|}
\hline \multicolumn{2}{|c|}{ Model } & \multicolumn{1}{|c|}{$\begin{array}{c}\text { Sum of } \\
\text { Squares }\end{array}$} & df & $\begin{array}{c}\text { Mean } \\
\text { Square }\end{array}$ & F & Sig. \\
\hline \multirow{2}{*}{1} & Regression & 871.134 & 1 & 871.134 & 71.374 & $.000^{\mathrm{b}}$ \\
& Residual & 781.136 & 64 & 12.205 & & \\
& Total & 1652.271 & 65 & & & \\
\hline
\end{tabular}

a. Dependent Variable: $S A$

b. Predictors: (Constant), $P A$

Sumber : Data Processing Results, 2020

Table 5. F Test Results with Moderating

\begin{tabular}{|l|l|r|r|r|r|r|}
\hline \multicolumn{2}{|c|}{ Model } & $\begin{array}{c}\text { Sum of } \\
\text { Squares }\end{array}$ & df & $\begin{array}{c}\text { Mean } \\
\text { Square }\end{array}$ & F & Sig. \\
\hline \multirow{2}{*}{1} & Regression & 901.274 & 2 & 450.637 & 37.803 & $.000^{\mathrm{b}}$ \\
& $\begin{array}{l}\text { Residual } \\
\text { Total }\end{array}$ & 750.997 & 63 & 11.921 & & \\
\hline
\end{tabular}

a. Dependent Variable: $S A$

b. Predictors: (Constant), MMP, PA

Sumber : Data Processing Results, 2020

From the results of the $\mathrm{F}$ test as presented in Table 4.35 and Table 4.36 above, the significance value (Sig) both without moderating and moderating is 0.000 . If this value is compared with a significance level $(\alpha)$ of 0.05 , it can be seen that the value of Sig is smaller than the value of $(0.000<0.05)$. Therefore, both linear regression models (equations 4.2 and 4.4) can be used for the next test.

Based on the results of the tests that have been carried out, the results of the t-test carried out without using a moderator are presented in Table 4.37 below :

Table 4.37

Results of t-test without moderating

\begin{tabular}{|c|c|c|c|c|c|c|}
\hline \multicolumn{7}{|c|}{ Coefficients ${ }^{a}$} \\
\hline & \multirow{2}{*}{ Model } & \multicolumn{2}{|c|}{$\begin{array}{c}\text { Unstandardized } \\
\text { Coefficients }\end{array}$} & $\begin{array}{l}\text { Standardized } \\
\text { Coefficients }\end{array}$ & \multirow[t]{2}{*}{$\mathrm{t}$} & \multirow[t]{2}{*}{ Sig. } \\
\hline & & B & Std. Error & Beta & & \\
\hline \multirow[t]{2}{*}{1} & (Constant) & 9.391 & 1.642 & & 5.719 & 0.000 \\
\hline & PA & 0.215 & 0.085 & 0.726 & 8.448 & 0.000 \\
\hline
\end{tabular}

a. Dependent Variable: $S A$

Sumber : Data Processing Results, 2020

The previous section stated that the first research hypothesis was stated that budget participation affects budgetary slack. The results of the tests that have been carried out and presented in Table 4.37 above show that the significance value (Sig) on the budget participation variable (PA) is 0.000 . If this value is compared with a significance level $(\alpha)$ of 0.05 , it can be stated that the significance value (Sig) is smaller than the significance level $(0.000<0.05)$. This shows that the first hypothesis can be accepted. That is, budget participation has a significant effect on budgetary slack.

In addition, if you look at the beta coefficient $(\beta)$ of the budget participation variable, it is positive $(0.215)$, then this condition indicates that budget participation has a positive effect on budgetary slack. This means that the higher the participation in budgeting, the greater the occurrence of budgetary slack. 
Furthermore, based on the results of the tests that have been carried out, the results of the t-test carried out using moderators are presented in Table 4.38 below:

Table 4.38

T-Test Results with Moderating

\begin{tabular}{|c|l|r|r|r|r|r|}
\hline \multicolumn{2}{|c|}{ Model } & \multicolumn{6}{|c|}{$\begin{array}{c}\text { Unstandardized } \\
\text { Coefficients }\end{array}$} & $\begin{array}{c}\text { Standardized } \\
\text { Coefficients }\end{array}$ & \multirow{2}{*}{$\mathrm{t}$} & \multirow{2}{*}{ Sig. } \\
\cline { 3 - 5 } \multicolumn{2}{|c|}{} & B & Std. Error & Beta & & \\
\hline \multirow{2}{*}{1} & (Constant) & 12.504 & 2.543 & & 4.917 & 0.000 \\
& PA & -0.288 & 0.281 & 0.292 & 1.024 & 0.031 \\
& MMP & -0.008 & 0.005 & 0.454 & 1.590 & 0.012 \\
\hline
\end{tabular}

a. Dependent Variable: $S A$

Sumber : Data Processing Results, 2020

In the previous section, it was stated that the second hypothesis of this study was stated that psychological capital could moderate the effect of budgetary participation on budgetary slack. The results of the tests that have been carried out and presented in Table 4.38 above show that the significance value (Sig) on the moderating variable of psychological capital (MPP) is 0.012 . If this value is compared with a significance level $(\alpha)$ of 0.05 , it can be stated that the significance value (Sig) is smaller than the significance level $(0.012<0.05)$. This shows that the second hypothesis of this study can be accepted. That is, psychological capital can moderate the effect of budgetary participation on budgetary slack. In addition, if you look at the beta coefficient $(\beta)$ of the moderating variable of psychological capital (MPP), it is negative (-0.215), then this shows that psychological capital as a moderating variable has a negative effect on budgetary slack. The higher the budgetary participation and accompanied by the higher the psychological capital will be able to suppress the occurrence of budgetary slack. In addition, not different from the results shown in the first hypothesis testing, budget participation still affects budgetary slack (significance value $0.031<$ significance level 0.05 ) with a negative direction. Therefore, with the use of psychological capital moderating variables, budgetary participation can reduce budgetary slack.

Next, test the coefficient of determination $\left(\mathrm{R}^{2}\right)$ aims to measure the ability of the model to explain variations in the independent variable (Ghozali, 2013). Therefore, the magnitude of the coefficient of determination $\left(\mathrm{R}^{2}\right)$ indicates how much the ability of the independent variable in explaining the dependent variable.

Based on the results of data processing, the regression results generated for the two hypotheses (without and with moderating) were tested, showing the value of the coefficient of determination as presented in Table 4.39 and Table 4.40 below:

Table 4.39

R-Square Test Results Without Moderating

\begin{tabular}{|c|c|c|c|c|}
\hline \multicolumn{5}{|c|}{ Model Summary $^{\mathbf{b}}$} \\
\hline \multirow{2}{*}{ Model } & R & R Square & $\begin{array}{c}\text { Adjusted R } \\
\text { Square }\end{array}$ & $\begin{array}{c}\text { Std. Error of } \\
\text { the Estimate }\end{array}$ \\
\hline 1 & $.726^{\mathrm{a}}$ & 0.527 & 0.520 & 3.4936020 \\
\hline
\end{tabular}

a. Predictors: (Constant), $P A$

b. Dependent Variable: $S A$

Sumber : Data Processing Results, 2020

Based on Table 4:39 above, the coefficient of determination $\left(\mathrm{R}^{2}\right)$ test results showed that the amount of $\mathrm{R}$ Square $\left(\mathrm{R}^{2}\right)$ is equal to 0.527 . This magnitude value indicates that the budget participation variable influences $52.70 \%$, while the remaining $47.30 \%$ is influenced by other variables not examined in this study.

Not much different from test results $\mathrm{R}^{2}$, without the moderating in Test $\mathrm{R}^{2}$ by using a moderating showed the following results :

Table 4.40

Results Test R-Square By moderating

\begin{tabular}{|c|c|c|c|c|}
\hline \multicolumn{5}{|c|}{ Model Summary ${ }^{b}$} \\
\hline Model & $\mathbf{R}$ & R Square & $\begin{array}{l}\text { Adjusted R } \\
\text { Square }\end{array}$ & $\begin{array}{l}\text { Std. Error of } \\
\text { the Estimate }\end{array}$ \\
\hline 1 & $.739^{a}$ & 0.545 & 0.531 & 3.4526194 \\
\hline
\end{tabular}

a. Predictors: (Constant), $M M P, P A$

b. Dependent Variable: $S A$

Sumber : Data Processing Results, 2020

Based on Table 4:40 above, the coefficient of determination $\left(\mathrm{R}^{2}\right)$ test results showed that the amount of RSquare $\left(R^{2}\right)$ is equal to 0.545 . This magnitude value indicates that the budget participation variable moderated by the psychological capital variable has an effect of $54.50 \%$, while the remaining $45.50 \%$ is influenced by other 
variables not examined in this study.

\section{DISCUSSION}

\section{The Effect of Budget Participation on Budgetary Slack}

Based on the results of the t-test that has been carried out above, the results show that the value of the significance level (Sig) of the budgetary participation variable is 0.000 . If this value is compared with a significance level $(\alpha)$ of 0.05 , it can be stated that the significance value (Sig) is smaller than the significance level $(0.000<0.05)$. This shows that the first hypothesis of this study can be accepted. Other information obtained from the results of this study shows that the beta coefficient $(\beta)$ of the budget participation variable is positive $(0.215)$. That is, budget participation has a positive and significant effect on budgetary slack. This means that the higher the level of budget participation will affect the increase in budgetary slack.

Budgetary slack will increase if government agencies increase budget participation by involving all heads of sections and subsections in budget preparation. This is very likely to happen if the leaders determine that income is too low with too high expenses (Mardiasmo, 2007: 36), so that it will provide inappropriate information (Siegel and Marconi, 1989). Therefore, budget participation will be artificial by making slack in the budget (Mowen, et al., 2019:28). Thus, budgeting by involving lower-level leaders will freely determine what will be achieved for their interests, but not the interests of organizations or agencies. By participating in budget preparation, employees will have a strong desire to try to achieve budget goals and perseverance in achieving budget goals (Nafinia, Fitriah, Lestari, 2019).

When viewed from testing the coefficient of determination, $\mathrm{R}$ Square $\left(\mathrm{R}^{2}\right)$ is equal to 0.527 . This information means that budgetary participation can affect $52.70 \%$, and the rest $(47.30 \%)$ is influenced by other variables that are not included in this study. These other variables include Environmental Uncertainty (Huseno, 2017), the effectiveness of budget control (Islami, 2016), information asymmetry and budget emphasis (Irfan, et al; 2016), job satisfaction (Çetin, 2011), and ethical ideology (Widodo, 2015 ).

In addition, empirically the results of this study also answer the phenomena that occur in the Bandung City Government where for 4 (four) years, namely from 2014 - 2017 there are always differences in the budget that have been set with those that have been realized, where the average the absorption capacity of budget realization is only $80 \%$. This condition will continue for the 2019 fiscal year, as stated by Sumarna (2019), as the Regional Secretary of the City of Bandung, who stated that until the end of 2019 the absorption capacity of the budget would still reach $80 \%$ as in previous years.

The results of this study are in line with the results of previous studies, such as research conducted by Dunk (2006), Sihombing (2017), Widodo (2015), Ernayati and Dharmadiaksa (2017), Jaya (2013), Tanaya \& Krisnadewi (2016), Rifqi \& Rahman (2017), Harryanto (2017), Pusporini, Haryadi \& Herwiyanti (2018), Basri, Rasuli \& Al-Azhar (2018), Pundarika \& Dwirandra (2019), Tangang, Usman \& Indrijawati (2018), Kepramareni , Pramesti \& Widiasih (2019), Mujiono, Chandrarin \& Assih (2019), Putra \& Astika (2019), Christina \& Akbar (2019), Apriwandi, Supriyono \& Arifa (2019), Oladele (2019), Wafiroh, Abdani \& Nurdin (2020), Carolina (2020), Ekayani, et.al (2021) which stated that budget participation has a positive effect on budgetary slack.

\section{The Effect of Budget Participation on Budgetary Slack Moderated by Psychological Capital}

Based on the results of the t-test that has been carried out above, the results show that the value of the significance level (Sig) of the psychological capital moderating variable (MMP) is 0.012 . If this value is compared with a significance level $(\alpha)$ of 0.05 , it can be stated that the significance value (Sig) is smaller than the significance level $(0.012<0.05)$. This shows that the second hypothesis of this study can be accepted. That is, psychological capital can moderate the effect of budgetary participation on budgetary slack. Other information obtained from the results of this study shows that the value of the beta coefficient $(\beta)$ of budget participation and the moderating variable of psychological capital (MMP) is negative $(-0.288$ and -0.008$)$, respectively. These results indicate that with the moderating variable of psychological capital, the initial relationship between budget participation and budgetary slack is positive to negative. The same thing is shown by the negative influence of the moderating variable of psychological capital (MMP) on budgetary slack.

If the coefficient of determination is seen from the test results, the R-square value $\left(\mathrm{R}^{2}\right)$ is equal to 0.545 . The magnitude of the value indicates that the variable is moderate budgetary participation by psychological capital variables influence $54,50 \%$, while the remaining $45.50 \%$ influenced by other variables not examined in this study. Furthermore, if the value of $\mathrm{R}^{2}$ (with and without the moderating) is compared, it can be seen that the value of $R^{2}$ without the moderating $(0.527)$ is smaller than the value of $R^{2}$ with the moderating $(0.545)$. These results indicate that an increase in the amount of $\mathrm{R}^{2}$ value of $0.018(0.545$ to 0.527$)$. Therefore, it can be concluded that the moderating variable of psychological capital, can strengthen the influence of budget participation on budgetary slack negatively.

The results of this study provide empirical evidence that if the level of participation in budgeting is higher with the encouragement of psychological capital owned by the parties participating in the budget, it will reduce 
the occurrence of budgetary slack. In other words, it can be interpreted that budgetary slack can decrease if local government agencies increase budget participation by involving all heads of sections and subsections in budgeting that have good psychological capital. This is by the statement put forward by Luthans, et.al (2008) that someone who has psychological capital describes that he has the potential and capacity that is formed to focus more on something positive. This is because the individual has positive psychological characteristics (Vankatesh, 2012), such as self-efficacy, hope, optimism, and resilience. Thus, if the individuals involved in budgetary participation have these four characteristics, they tend not to commit budgetary slack (Vankatesh, 2012).

The results of this study are in line with several previous studies, such as research conducted by Vankatesh (2012) which shows that when the four characteristics of psychological capital are owned and developed in individuals, it will lead to motivation in reducing budgetary slack. This study is also consistent with research in the public sector conducted by Nuryani, et al (2018), such as hospitals. The results of this study indicate that the psychological capital variable can mediate the effect of budgetary participation in reducing the occurrence of budgetary slack, as well as other studies such as those conducted by Tatang, et al (2018), Septiana \& Budiasih (2018), Dwiprayuda \& Wiratmaja (2019), Suriani, et al. (2018), Suriani \& Nohong (2017), Putra \& Suryanawa (2019).

\section{CONCLUSION}

Based on the results of the research and discussion that have been described previously, it can be concluded:

1) Budget participation has a positive effect on budgetary slack. These results indicate that the higher the participation in budgeting, the more the budgetary slack in its implementation will be increased.

2) Psychological capital can moderate the influence of budgetary participation on budgetary slack. These results mean that with a solid psychological capital within the individual who participates in budgeting, they will reduce the occurrence of budgetary slack.

\section{REFERENCES}

Agus Aditya Pramana Putra, P., \& Suryanawa, I. K. (2019). Pengaruh Partisipasi Anggaran Pada Budgetary Slack dengan Self Esteem dan LOC Sebagai Variabel Pemoderasi. E-Jurnal Akuntansi. https://doi.org/10.24843/eja.2019.v27.i01.p09

Amir, A. M., Ridwan, Din, M., Yamin, N. Y., Zahra, F., \& Firman, M. F. (2020). The role of budget participation in improving managerial performance. Accounting, $7(2)$. https://doi.org/10.5267/j.ac.2020.12.004

Anthony, R. ., \& Govindaradjan, V. (2004). Management Control System (11th ed.). Mc Grow Hill.

Apriwandi, Supriyono, \& Choirunnisa, A. (2020). The Moderation Effect of Power Distance Orientation and Leadership Personality on Budget Participation and Relationship of University Performance in Indonesia. https://doi.org/10.2991/aebmr.k.200410.001

Basri, H. (2018). Pengaruh penganggaran partisipatif, self esteem, locus of control, kapasitas individu dan komitmen organisasi terhadap budgetary slack (Studi Pada OPD Kota Pekanbaru. JOM FEB, 1(JanuariJuni).

Carolina, Y. (2020). Participative Budgeting, Employee Motivation and Budgetary Slack in Private Sector in Indonesia. Jurnal ASET (Akuntansi Riset, 12(2).

Çetin, F. (2011). The effects of the organizational psychological capital on the attitudes of commitment and satisfaction: A public sample in Turkey. European Journal of Social Sciences, 21(3).

Christina, V., \& Akbar, S. (2019). The influence of budget participation on budgetary slack with organizational commitment as a moderator variable (A study on performance sustainability of SOES Bandung). Journal of Advanced Research in Dynamical and Control Systems, 11(3Special Issue).

Dunk, A. S. (1993). The Effect Relation of Budget Between Emphasis the Budgetary Slack and Information Asymmetry on Participation and Slack. The Accounting Review, 68(2).

Dwiprayuda, A. A. N. B., \& Wiratmaja, I. D. (2019). Self Esteem Dan Group Cohesiveness Sebagai Pemoderasi Pengaruh Partisipasi Anggaran Pada Budgetary Slack. E-Jurnal Akuntansi. https://doi.org/10.24843/eja.2019.v26.i01.p16

Ekayani, N. N. S., Sariani, N. K., Warsa, A. K. J., Putra, I. G. B. N. P., \& Sinarwati, N. K. (2021). Organizational Culture Moderates Organizational Commitment and Participation of Budget Development on Budget Slack. South East Asia Journal of Contemporary Business, Economics and Law, 24(1), 132-135.

Erina, N. P. D., \& Suartana, W. (2016). Pengaruh Partisipasi Penganggaran, Penekanan Anggaran, Kapasitas Individu, dan Kejelasan Sasaran Anggaran Pada Senjangan Anggaran. E-Jurnal Akuntansi Universitas Udayana, 15(2).

Ernayanti, N. P., \& Dharmadiaksa, I. B. (2017). Pengaruh Partisipasi Penganggaran Pada Senjangan Anggaran Dengan Karakter Personal Pesimis Sebagai Variabel Pemoderasi. E-Jurnal Akuntansi Universitas Udayana, 
19(2).

Ghozali, I. (2013). Aplikasi Analisis Multivariat dengan Program IBM SPSS 23 (8th ed.). Universitas Diponegoro.

Harryanto. (2017). The Effect Budget Satisfaction and Organizational Fairness in Local Government Budget Participation Process. Review of Integrative Business 7 Economics Research, 6(1), 44-74.

Huseno, T. (2017). Organization Commitment and Enviromental Uncertainty Moderating Budget Participation On Budgetary Slack. Jurnal Aplikasi Manajemen, 15(1), 106-115.

Irfan, M., Santoso, B., \& Effendi, L. (2016). Pengaruh Partisipasi Anggaran terhadap Senjangan Anggaran dengan Asimetri Informasi, Penekanan Anggaran dan Komitmen Organisasi sebagai Variabel Pemoderasi. Jurnal Akuntansi Dan Investasi, 17(2), 158-175.

Islami, M. (2016). Pengaruh Partisipasi Anggaran dan Efektifitas Pengendalian Anggaran Terhadap Timbulnya Kesenjangan Anggaran yang di Moderating Oleh Gaya Kepemimpinan. Jurnal Akuntansi, 3(1).

Jaya, M. F. D. (2013). The effects of budget participation, asymmetric information, budget emphasis, and organizational commitment on budgetary slack in Pemerintah Kota Pasuruan. Jurnal Akuntansi, 3(1).

Kepramareni, P., Pramesti, I. G. A. A., \& Widiasih, S. (2019). Effect of Participative Budgeting on Budgetary Slack With Asymmetry Information, Leadership Style and Organizational Commitment As Moderation Variables. International Journal of Applied Science and Sustainable Development (IJASSD), 1(1).

Luthans, F., Norman, S. M., Avolio, B. J., \& Avey, J. B. (2008). The mediating role of psychological capital in the supportive organizational climate - Employee performance relationship. Journal of Organizational Behavior, 29(2). https://doi.org/10.1002/job.507

Mardiasmo. (2007). Akuntansi Sektor Publik. Penerbit Andi.

Mowen, M. ., Hansen, D. ., \& Heitger, D. . (2019). Dasar-Dasar Akuntansi Manajerial, Cetakan Kedua, diterjemahkan oleh Catur Sasongko. Salemba Empat.

Mujiono, M., Chandrarin, G., \& Assih, P. (2019). The Role of Information Asymmetry in Moderating The Influence of Organizational Commitments and Budgeting Participation Towards Budgeting Gap in PIUI in East Java. International Journal of Business and Applied Social Science. https://doi.org/10.33642/ijbass.v5n12p7

Mulyadi. (2001). Akuntansi Manajemen : Konsep, Manfaat dan Rekayasa (Ketiga). Penerbit Salemba Empat.

Nafarin, M. 2015. Penganggaran Perusahaan. Jakarta : Penerbit Salemba Empat.

Nafinia, Dita, Fitriah, Epi dan Lestari, Rini. 2016. Pengaruh Partisipasi Penyusunan Anggaran dan Komitmen Organisasi Terhadap Kinerja Manajerial;. Prosiding Akuntansi SPeSIA, Vol 2, No 2.

Nazir. 2014. Metode Penelitian. Jakarta: Penerbit Ghalia Indonesia.

Nuryani, Y., Fallah, S., \& Pangayow, B. J. (2018). Pengaruh Partisipasi Anggaran terhadap Budgetary Slack dengan Psycological Capital sebagai Variabel Intervening (Studi Empiris pada Rumah Sakit di Kota Jayapura). Jurnal Akuntansi \& Keuangan Daerah, 13(1).

Oladele, O. M., \& Hou Longlong. (2019). The Influence Of Faculty Budgetary Participation, Budget Adequacy, Values And Vision On Staff Performance: A Case Study Of University Of Ibadan, Nigeria. Journal of Economics and Economic Education Research, 20(3), 1-18.

Pundarika, I. G. P., \& Dwirandra, A. A. N. . (2019). The Effect of Budget Participation on Budgetary Slack with Organizational Commitments and Love of Money as Moderation. International Journal of Science and Research (IJSR), 8(2).

Pusporini, I., Pusporini, I. D., HARYADI, H., \& HERWIYANTI, E. (2018). The Effect of Budget Participation on Budgetary Slack with Information Asymmetry and Organizational Commitment as a Moderating Variable. Journal of Research in Business, Economics and Management, 12(1), 2261-2269. http://scitecresearch.com/journals/index.php/jrbem/article/view/1644

Putra, I. N. W. A., \& Astika, I. B. P. (2019). Budget Participation and Budgetary Slack: The Effect Mediation Testing of Justice Perception (Study on Regional Apparatus Organization in Badung Regency-Bali Indonesia). International Journal of Economics, Commerce and Management, VII. http://ijecm.co.uk/

Rifqi, R. A., Subekti, I., \& Rahman, A. F. (2017). The Effect of Budget Participation to Budgetary Slack With External Pressure as Moderating Variable. Journal of Accounting and Business Education, 1(1). https://doi.org/10.26675/jabe.v1i1.9757

Sekaran, Uma, Roger Bougie, Roger. 2016. Research Methode for Business A Skill Building Approach. Seventh Edition. United Kingdom: John Wiley \& Sons Ltd.

Septiana, I. G. A., \& Budiasih, I. G. A. N. (2018). Karakter Personal sebagai Pemoderasi Pengaruh Partisipasi Penganggaran Pada Senjangan Anggaran di BPR Kabupaten Gianyar. E-Jurnal Akuntansi. https://doi.org/10.24843/eja.2018.v22.i01.p24

Siegel, G., dan H.R. Marconi, 1989. Behavioral Accounting. South Western Publishing, Co. Cincinnati, OH.

Sihombing, M. Y., \& Rohman, A. (2017). Analisis Pengaruh Anggaran Partisipatif terhadap Budgetary Slack dengan Pertimbangan Etika sebagai Variabel Moderasi (Studi Kasus pada PT Pln (Persero) Distribusi Jawa 
Tengah \& D.i. YOGYAKARTA). Diponegoro Journal of Accounting, 6(3).

Sugiyono. 2017. Metode Penelitian Kuantitatif, Kualitatif, dan R\&D. Bandung : Alfabeta. 2014. Metode Penelitian Kuantitatif Kualitatif dan R\&D. Bandung: Alfabeta.

Suriani, S, Alam, S., \& Nohong, M. (2017). Advances in Economics, Business and Management Research, volume 40 2nd International Conference on Accounting, Management, and Economics (ICAME 2017). 40(Icame), 400-406.

Suriani, Seri, Alam, S., Nursyamsi, I., Nohong, M., \& Filho, F. de S. P. (2018). Moderation of Information Asymmetry, Self Esteem to the Effect of Participatory Budgeting on Budgetary Slack Government of South Sulawesi Province. International Journal of Advanced Engineering Research and Science, 5(8), 1-6. https://doi.org/10.22161/IJAERS.5.8.1

Tahang, N. ., Usman, A., \& Indrijawati, A. (2018). The Effect of Information Asymmetry, Budget Participation and Individual Capacity on Budgetary Slack by Organization Culture as The Moderation Variable (Empirical Study on SKPD Soppeng Regency). International Journal of Advanced Research (IJAR), 6(12), 1235-1245. https://doi.org/10.21474/IJAR01/8258

Tanaya, I. G. M. L., \& Krisnadewi, K. A. (2016). Pengaruh Partisipasi Penganggaran pada Kesenjangan Anggaran Dengan Karakter Personal Sebagai Pemoderasi. E-Jurnal Akuntansi Universitas Udayana, 17(3).

Venkatesh, R. (2014). The Budget Participation-Budgetary Slack Relationship: The Role of Psychological Capital (PsyCap). Journal of Theoretical Accounting Research, 9(2).

Venkatesh, R., \& Blaskovich, J. (2012). The mediating effect of psychological capital on the budget participation-job performance relationship. Journal of Management Accounting Research, 24(1). https://doi.org/10.2308/jmar-50202

Wafiroh, N. L., Abdani, F., \& Nurdin, F. (2020). Budget Participation and Budgetary Slack: The Mediating Effect of Autonomous Budget Motivation. Jurnal Akuntansi, 10(3). https://doi.org/10.33369/j.akuntansi.10.3.287-300

Widodo, H. S. (2015). Pengaruh Komitmen Organisasional Terhadap Senjangan Anggaran dengan Ideologi Etis SebagaiVariabel Pemoderasi. Jurnal Akuntansi, 16(01), 160-171.

Young, S. M. (1985). Participative Budgeting: The Effects of Risk Aversion and Asymmetric Information on Budgetary Slack. Journal of Accounting Research, 23(2). 